\title{
Farmer monitoring reveals the effect of tidal height on mortality risk of oysters during a herpesvirus outbreak
}

\author{
Pernet Fabrice ${ }^{1,}{ }^{\star}$, Gachelin Sonia ${ }^{2}$, Stanisière Jean-Yves ${ }^{3}$, Petton Bruno ${ }^{1}$, Fleury Elodie ${ }^{1}$, \\ Mazurié Joseph ${ }^{3}$
}

${ }^{1}$ Laboratoire des Sciences de l'Environnement Marin (LEMAR), UMR 6539 UBO/CNRS/IRD/lfremer, CS 10070, Ifremer, Plouzané, France

${ }^{2}$ Comité régional de la conchyliculture de Bretagne Sud, ZA Porte Océane, 7 rue du Danemark, Auray, France

3 Unité Littorale, Laboratoire Environnement Ressource du Morbihan Pays-de-la-Loire, Ifremer, 12 Rue des Résistants, La Trinité-sur-Mer, France

* Corresponding author : Fabrice Pernet, email address : Fabrice.Pernet@ifremer.fr

\begin{abstract}
:
The intertidal zone is characterized by a sharp vertical gradient of environmental stress, which structures species distribution and their interactions. Few studies, however, have examined the influence of tidal height on host-pathogen interactions. Here, we investigated how the tidal height influence outbreak of the Ostreid herpesvirus type 1 (OsHV-1) affecting the Pacific oyster. A volunteer network composed of 20 oyster growers monitored the survival of 28 batches of oysters during an epizootic event in Southern Brittany, France. Oysters were spat from wild collection or hatchery production. The sampling sites were spread over a $150-\mathrm{km} 2$ area with a tidal height ranging from 0.98 to $2.90 \mathrm{~m}$. Concomitantly, we followed survival of oyster spats in relation with OsHV-1 DNA detection at two sites and conducted risk analysis. We found that tidal height was associated with a lower risk of mortality. This effect was higher for hatchery than for wild oysters probably reflecting differences in health status. Our study opens perspectives for mitigation strategies based on tidal height and emphasizes the value of volunteer science in marine epidemiological studies.
\end{abstract}

Keywords : citizen science, marine epidemiology and health, OsHV-1, risk analysis. 
33 Since the mid-1970s, disease epidemics and mass mortalities have been occurring in marine

environments at a historically unprecedented rate (Harvell et al., 1999) with consequences for

fisheries and aquaculture (Lafferty et al., 2015). The risk of disease outbreak depends on

interactions between hosts, pathogens, and the environment, and any change in one or more

37 of these components may potentially increase or decrease this risk (Burge et al., 2014). The

intertidal zone is characterised by a vertical gradient of environmental stress with increasing

elevation which structure species distribution, zonation and community dynamics (Connell,

1972). This feature makes it an important model system for marine ecological studies.

Nevertheless, few studies have examined the influence of tidal height on host-pathogen interaction (but see Burrell et al., 1984; Ben-Horin et al., 2013; Malek and Breitburg, 2016; Malek and Byers, 2017). It is likely that host species that spend less time underwater are less exposed to pathogens vectored by the seawater. Also, replication or proliferation of obligate parasites that depend on the host cell machinery is probably altered because host metabolism and growth are lowered (Widdows et al., 1979; Somero, 2002).

47 One of the most striking examples of recent disease emergence is the Pacific Oyster Mortality 
France (AHAW, 2015; Barbosa Solomieu et al., 2015; Pernet et al., 2016; Alfaro et al., 2018). Almost all French production areas were severely hit by POMS, thus resulting in a supply shortage and a rise in prices (Le Bihan et al., in press). This syndrome is caused by the ostreid herpesvirus 1 (OsHV-1) which alters the immune state of oysters and leads to fatal bacteraemia and death (de Lorgeril et al., 2018). Epizootics caused by OsHV-1 occur every year when seawater temperature is between $16^{\circ} \mathrm{C}$ and $24^{\circ} \mathrm{C}$ in France (Pernet et al., 2012; Renault et al., 2014). Infection starts when viral particles come into contact with susceptible hosts via suspension feeding. There is a threshold dose for infection and a dose-response effect of OsHV-1 on mortality (Paul-Pont et al., 2015; Petton et al., in revision). Like other herpesviruses, latent and asymptomatic OsHV-1 infections are able to persist in hosts (Segarra et al., 2014). In this case, virus reactivation can occur several weeks to months after initial exposure (Pernet et al., 2015; Petton et al., 2015), viral particles are shed into the water column and dispersal to new hosts occurs via water currents (Pernet et al., 2012). The economic costs associated with increased oyster mortalities have promoted investigation of disease risk factors to improve management of shellfish farms, but the effect of tidal height has rarely been investigated (Pernet et al., 2016).

A review of early experiments conducted in France during the first disease outbreaks suggest that tidal height can be associated with lower mortality of oysters (Soletchnik et al., 2011). This hypothesis has only been partially confirmed. High rearing height is related to reduced mortality in adults but not in spats for which only a mortality delay occurs (Paul-Pont et al., 2013; Whittington et al., 2015a). More recently, tidal height is associated with a lower risk of mortality in only 9 out of 40 tested oyster spat families (Azema et al., 2017). Broad-scale epidemiological studies reveal apparently conflicting results. A survey conducted in Irish 
oyster farms suggests that emersion time is negatively associated with mortality (Peeler et al., 2012) but another one carried out in Australia shows no relation (de Kantzow et al., 2017).

Mortality risk factors associated with OsHV-1 have recently been identified along an inshoreoffshore gradient in permanently immersed animals, but not in inshore farming areas where animals are held at various tidal heights and are regularly emerged (Pernet et al., 2018). Here we supplemented this epidemiological study focusing on the farming areas. The objective was to investigate the effect of tidal height on mortality risk of oysters. An original aspect to the present study is that survival of farmed oysters was monitored by a network of growers to obtain simultaneous data from multiple remote sites. The results obtained by oyster growers were strengthen by the Ifremer observatory network of oyster mortality. Although the roots of citizen science go back to the very beginnings of modern science, projects in which volunteers associate with scientists are new in the field of marine epidemiology (Foster-Smith and Evans, 2003; Silvertown, 2009; Dickinson et al., 2010).

\section{Material and method}

\section{Study site}

The study sites covered a surface area of $c a .150 \mathrm{~km}^{2}$ located in South Brittany, France, and encompass six production areas located in inlets, rivers or gulfs where oysters were hit by OsHV-1 every year since 2008 (Figure 1) (Fleury et al., 2018). Although the number of oyster companies in this area has decreased by $25 \%$ since 2001 partly because of the virus, there were 241 companies in 2012 that supported 522 full-time jobs (Agreste, 2014). The coastline is heterogenous, alternating bedrock, sandy beaches and sandy-loamy to sandy-muddy tidal flats. However, the large majority of oysters (70\%) are cultivated off-bottom in mesh bags 
attached to iron tables (Buestel et al., 2009). This area is influenced by semi-diurnal tides and the tidal range was between $0.22 \mathrm{~m}$ and $5.88 \mathrm{~m}$ during the study period.

\section{Volunteer network}

The experimental design was set-up in collaboration with local oyster farmers. Oyster growers were informed by the regional shellfish committee that participatory monitoring of large-scale oyster mortalities was taking place and that volunteers were needed to survey their own concessions. A meeting was held with all respondents in mid-April 2013 to outline the monitoring protocol. Twenty farmers agreed to participate to the experiment. Farmers were in charge of one ( $\mathrm{N}=14$ farmers), two $(\mathrm{N}=4)$ or three $(\mathrm{N}=2)$ batches of oysters for a total of 28 batches (\#1-28). The sentinel oysters were chosen among the farmed stock by the farmers themselves. To be included in the experimental design, the sentinel oysters needed be at the spat stage and free of abnormal mortality since they arrived at the monitoring site. At the onset of the monitoring, sentinel oysters were 10 to $25 \mathrm{~mm}$ shell length and they had spent between 8 and 205 days on the farm (mean=70 \pm 64 days). The sentinel oysters were deployed after 15 October 2012 when seawater temperature was $<16^{\circ} \mathrm{C}$, so that OsHV-1 infection at the monitoring site was unlikely. They originated from hatcheries or from natural collection in the wild. Oysters from hatcheries were not genetically selected for disease resistance. At the time of this study, work on OsHV-1 oyster resistance in France was conducted on an experimental scale only. In fact, some private hatcheries and the National Shellfish Committee launched their own breeding programs in 2013-14 (Dégremont et al., 2015). Wild oysters were settled on limed tiles or plastic tubes during the preceding summer and the spat were removed during the fall or early winter according to standard practices (Heral, 1989). Wild oysters generally spent more time on the farm before the start of monitoring than those from 
119

120

121

122 123 Service Hydrographique et Océanographique de la Marine (SHOM). The survival monitoring 124

hatcheries (116 vs. $40 \mathrm{~d}$ respectively). A subsample $(n=100)$ of the farmed stock selected as sentinels was transferred into small mesh bags $(22 \times 20 \times 2 \mathrm{~cm}, \varnothing=6.0 \mathrm{~mm})$ attached to iron tables. Farmers provide exact positions of each oyster bag, the date of arrival on the rearing site and the origin of the oysters (wild or hatchery). Bathymetric data were provided by the started on 8 May 2013, before the onset of the epizootics, and lasted for $133 \mathrm{~d}$ until 18 September 2013. Live and dead animals were counted twice a month by the farmer, generally during spring tides (22 and 29 May, 12 and 26 June, 10 and 24 July, 8 and 22 August and 6 and 18 September).

\section{Observatory network}

The Ifremer observatory network followed the survival of two batches of oyster spats originating from both wild or hatchery production at two sites located within the farming areas (\#29-32, Figure 1). Oysters consisted of (i) wild spat collected on limed tiles in Arcachon Bay during summer 2012 or (ii) 3-month-old animals produced by a private hatchery. These two batches of oysters were gathered at the Ifremer laboratory (La Trinité-sur-Mer, France) between 10 and 26 March 2013. Before deployment in the field, a subsample of 50 oysters from each batch were individually screened for OsHV-1 DNA by qPCR and exposed to a thermal elevation at $21^{\circ} \mathrm{C}$ for one month in cohabitation with healthy spats to reveal both disease expression and transmission (Petton et al., 2015). Wild oysters were asymptomatic carriers of OsHV-1 as the virus was detected in 3 out of 50 individuals and mortalities associated with OsHV-1 occurred in both the tested and the cohabited healthy oysters after thermal elevation at $21^{\circ} \mathrm{C}$ (see table $\mathrm{S} 1$, batch $\mathrm{n}^{\circ} 42$ in Petton et al., 2015). In contrast, oysters from the hatchery were considered specific-pathogen-free because OsHV-1 DNA was not 
detected and no mortality occurred after thermal elevation at $21^{\circ} \mathrm{C}$ (see table $\mathrm{S} 1$, batch $\mathrm{n}^{\circ} 40$

144 in Petton et al., 2015).

145 These two batches of oysters were placed in three regular-sized mesh bags per site (350

146 individuals per bag). Live and dead animals were counted twice a month during spring tides

147 from April to December in one of the three bags. Only survival data collected at the same time

148 as the farmers were considered. Three pools of three live hatchery oysters were collected

149 from early May to mid-September in each bag and analyzed for the detection and 150 quantification of OsHV-1 DNA (one pool per bag) by LABOCEA (Quimper, France) using a 151 standard real-time PCR protocol (Pepin et al., 2008). Seawater temperature was measured 152 every 15 minutes using temperature probes placed in one oyster bag at each site.

\section{Statistics}

155 Nonparametric estimates of the survivor function were computed using the Kaplan-Meier 156 method (Kaplan and Meier, 1958). Survival time was measured as number of days after 8 May, 157 the onset of the monitoring period, until 18 September 2013. The data were read as the 158 number of dead animals within each bag at each time interval. Survival curves were presented 159 for each oyster bag as a function of rearing site and origin of oysters. A Frailty model 160 (Hougaard, 1995) was fitted to survival data to investigate the effect of tidal height, origin and 161 their interaction. The Frailty model is a proportional Cox regression model (Cox, 1972) with a 162 random effect (site). Then, survival probabilities predicted by the model were plotted for every set of significant covariates or their interactions. These analyses were conducted with the LIFETEST and PHREG procedures of the SAS software package (SAS 9.4, SAS Institute).

\section{Results}


Survival was measured on 32 wild ( $n=20$ batches) or hatchery ( $n=12$ batches) oyster batches, spread over 22 sites within 6 production areas. Tidal height for these sites ranges from 0.98 to $2.90 \mathrm{~m}$ (mean $\pm \mathrm{SD}=1.94 \pm 0.67 \mathrm{~m}$ ), corresponding to an immersion time varying between 59.3 to $96.9 \%$ (mean $\pm S D=78.9 \pm 13.3 \%$, Figure 2 ).

The oysters were hit by the mass mortality event at all sites (Figure 3). Mortality was first observed 35 to 49 days after the onset of the monitoring (i.e. 12 to 26 June) for 20 batches out of 32. Survival functions of oysters differed depending on their origin (Figure 2, log-rank test, $\left.\chi^{2}=20.0, p<0.001\right)$. Indeed, mortality occurred earlier for wild than for hatchery oysters. Final survival varied widely from 20 to $97 \%$ (mean=51.0 $\pm 20.4 \%$ ) and it was similar between origin (wild: $49.5 \%$ vs. hatchery: $53.5 \%, \chi^{2}=1.8, p=0.187$ ). The observatory network revealed that these mortalities occurred while seawater temperature exceeded $16^{\circ} \mathrm{C}$ and coincided with the detection of high levels of OsHV-1 DNA in oyster tissues $\left(>10^{6} \mathrm{cp} \mathrm{mg} \mathrm{g}{ }^{-1}\right.$ wet tissue, Figure 4).

The relationship between the mortality risk and site, tidal height and origin of oysters was investigated using the Cox regression model (Table 1). Oyster origin and tidal height exerted a major influence on survival. Tidal height was associated with a lower mortality risk, with a greater effect on oysters originating from hatcheries than for those from the wild (Table 1). Any $1 \mathrm{~m}$ increase in tidal height led to a $48.8 \%$ reduction in mortality hazard for hatchery oysters compared to only $15.7 \%$ for wild oysters. Hazard ratios were 0.512 (95\% confidence interval $[\mathrm{Cl}]=0.452-0.580)$ and $0.843(0.764-0.930)$ respectively. Survival probabilities predicted by the model at the end of the monitoring of hatchery oysters held at $0,0.98,1.95$ and 2.90 m were respectively $19 \%, 40 \%, 61 \%$ and $76 \%$, compared to $42 \%, 44 \%, 47 \%$ and $50 \%$ for wild oysters (Figure 5A). Therefore, tidal height had more influence on the survival of hatchery oysters than on wild oysters. The mortality risk was the same for both wild and 
$\mathrm{m}$, any increase reduced the risk of wild oyster mortality to a lesser extent than that of hatchery oysters, which meant that the survival of wild oysters was lower than that of hatchery oysters. Conversely, at tidal height below $1.2 \mathrm{~m}$, any decrease increased the risk of 196 hatchery oyster mortality to a greater extent than that of wild ones, conferring a higher survival on hatchery compared to wild oysters.

\section{Discussion}

Here we validate the hypothesis that increasing tidal height decreases the risk of oyster 201 mortality during an OsHV-1 epizootic, as indicated for adult oysters in Australia and some spat 202 families in France (Paul-Pont et al., 2013; Whittington et al., 2015a; Azema et al., 2017). 203 Improved survival with increasing tidal height can be explained by a shorter immersion time, 204 leading to a lower exposure to viral particles in the water. Indeed, survival of healthy oysters 205 in laboratory conditions decreases with cohabitation time with infected oysters and reflects 206 the cumulative exposure to OsHV-1 (Petton et al., in revision). In line with this, survival of 207 oysters decreases with biomass of infected oysters and increases with seawater renewal, two 208 parameters that influence pathogen concentrations (Petton et al., 2015). Also, survival of 209 oysters injected with OsHV-1 decrease with increasing viral particle concentration (Paul-Pont et al., 2015; Segarra et al., 2016). Therefore, oysters that spend less time immerged will be 211 less exposed to OsHV-1 particles vectored by seawater and show higher survival.

212 In addition, since herpesviruses replication is directly dependent on host cell activity, it may 213 be reduced during emersion as metabolism and growth of the host decline (Widdows et al., 214 1979; Somero, 2002). For instance, virus replication in shrimp depends on cellular growth and 
215 proliferation of the host (Su et al., 2014). Further to this, fast-growing oysters are more 216 susceptible to OsHV-1 is than slow-growers (Pernet et al. unpublished data).

217 Finally, differences in temperature regime between low and high tidal levels could also 218 contribute to differences in survival of oysters exposed to OsHV-1. Indeed, during daytime 219 exposure at low tide, the body temperature of a shelled mollusks can rapidly rise from that of 220 the ambient seawater to $15^{\circ} \mathrm{C}$ above air temperature (e. g. Helmuth, 1999). In parallel, high 221 temperature $\left(>26^{\circ} \mathrm{C}\right)$ decreased the susceptibility of oysters to OsHV-1 (Petton et al., 2013; de 222 Kantzow et al., 2016; Delisle et al., 2018). It is possible that longer exposure to higher air 223 temperature at low tide makes oysters less susceptible to the virus at high tidal level. Lower 224 virus exposure, reduction of metabolic rate and exposure to high air temperature during emersion are not mutually exclusive hypotheses, and further studies are necessary to identify 226 which mechanism prevails. Interestingly, we found that the mortality risk of wild oysters was generally less influenced 228 by the tidal height than that of hatchery ones. A likely and logical hypothesis relate to differences in their initial health status. Indeed, wild oysters used in the observatory network were asymptomatic carriers of the virus whereas hatchery oysters were free of OsHV-1. This observation is in line with a major study showing that $60 \%$ of the wild oyster batches tested in France are asymptomatic carriers of OsHV-1 during their first winter, exhibiting mortality after thermal elevation and infecting cohabiting healthy hatchery oysters, whereas those from hatcheries and nurseries are free of OsHV-1 (Petton et al., 2015). Indeed, wild oysters are unpredictably exposed to the pathogen during their early life history whereas those from the hatcheries are generally protected from disease by means of prophylactic measures (Petton et al., 2015; Whittington et al., 2015b). It is therefore highly likely that a majority of wild oyster 
batches used in the volunteer network were initially asymptomatic carriers of the disease

239 while hatchery oysters were free of OsHV-1.

240 Lower influence of tidal height on the mortality risk in wild oysters compared to that of 241 hatchery oysters could also be explained by the fact that (i) tidal height decreased the risk of 242 oyster mortality by reducing viral exposure during emersion and (ii) the mortality risk of wild 243 animals, which were presumably asymptomatic carriers of the virus, was less dependent on 244 external sources of virus particles than that of hatchery oysters which were presumably free 245 of OsHV-1. Indeed, mortality risk of oysters is associated with the cumulative exposure to OsHV-1 (Petton et al., in revision) and the reactivation of the virus in asymptomatic carriers 247 does not require additional exposure to the pathogen; a thermal elevation beyond the permissivity threshold $\left(16^{\circ} \mathrm{C}\right.$ in Europe) is sufficient (Pernet et al., 2015; Petton et al., 2015). More particularly, survival of hatchery oysters was higher than that of wild oysters at tidal heights $>1.2 \mathrm{~m}$ (immersion time $<89.6 \%$ ) but for tidal heights $<1.2 \mathrm{~m}$ the opposite was true. At tidal heights $>1.2 \mathrm{~m}$, regular emersion may have partially protected hatchery oysters from pathogens, whereas wild oysters most likely died because the virus reactivated when seawater temperature increased to $16^{\circ} \mathrm{C}$. Conversely, at lower tidal levels, hatchery oysters were at higher risk of mortality because the presumed protection from emersion was 255 decreased, and their susceptibility to disease was greater than that of wild oysters. As wild oysters are more likely to be exposed to the pathogen than their hatchery counterparts, they are also more likely to be selected for greater resistance to the disease (Dégremont, 2011;

258 Pernet et al., 2012). It is possible, however, that confounding effects other than health status 259 were associated with oyster origins and contributed to the interactive effect of tidal height 260 and the origin of oysters. 
We also found that the onset of mortality in wild oysters occurred earlier than in hatchery

262

263

oysters. Similarly, OsHV-1 outbreaks are first manifest in wild oysters followed by those from hatcheries and nurseries (Pernet et al., 2010; Degremont and Benabdelmouna, 2014). This likely reflects the reactivation of the virus in wild oysters (asymptomatic carriers) as soon as the seawater temperature reached $16^{\circ} \mathrm{C}$, thus leading to an earlier death of the host. In hatchery oysters (presumably free of OsHV-1), mortality would appear not only above a certain temperature threshold, but after exposure to the virus and infection. Therefore, the lag between mortality outbreaks of asymptomatic carriers and healthy oysters probably corresponds to the time required for disease transmission, infection and expression once environmental conditions have become permissive.

Here we showed a beneficial effect of tidal height on oyster survival during an OsHV-1 epizootic. However, increasing tidal height is not always associated with higher oyster survival (Paul-Pont et al., 2013; Whittington et al., 2015a). Indeed, tidal height delays the onset of spat mortality without increasing final survival (Whittington et al., 2015a). Although there is no apparent reason for delaying mortality if there is no survival gain at the end, this is a first step towards increasing survival and restoring the health of ecosystems. Therefore, studies to define the risk factors for disease management should consider the survival dynamics rather than the end-point.

We therefore propose that farmers may mitigate oyster mortality by temporarily raising the culture height during the OsHV-1 mortality period, when seawater temperature is above $15^{\circ} \mathrm{C}$. Oyster mortality mitigation strategies based on tidal height have already been suggested (Peeler et al., 2012; Paul-Pont et al., 2013; Whittington et al., 2015a). Such a practice would be particularly relevant for oysters under one year old which are the most susceptible to the virus, and for oysters that are initially free of OsHV-1. However, to limit stunting due to the 
reduced feeding time that comes with increased emersion, farmers may consider lowering

the culture height during the second summer, once oysters have become more resistant to

287 the virus.

In line with this, rearing height of oyster spat in Australia was changed in response to OsHV-

2891 on $47 \%$ of leases, and $26 \%$ of these observed higher mortality when oysters were held low

290 in the intertidal zone (Ugalde et al., 2018). Yet, farmers consider this factor to be moderately

291 important in limiting the losses caused by the virus. Also, a survey of 93 growers spread over

292 two French farming areas (including the region covered by this study) conducted in 2014

293 reveals that $75 \%$ of them think that changing the rearing height is not an effective measure

294 for controlling oyster mortalities caused by the virus (Le Bihan, Lupo and Pernet, unpublished

295 data). This probably reflects that the effect of tidal height on oyster mortality is not

296 straightforward as it interacts with the origin of oysters, and more particularly with their initial

297 health status (OsHV-1-free or asymptomatic carrier, this study) or their genetic make-up

298 (Azema et al., 2017). These interactions could skew the point of view of the growers.

299 Finally, we must evaluate the economic efficiency of such a measure. Does the survival gain

300 compensate for reduced growth and increased handling? Then, we must assess acceptability,

301 that is the willingness of farmers to put into action disease control measures. In France, oyster

302 leases at high tide are usually dedicated to storing commercial oysters to limit their growth

303 until they are shipped to markets. As a result, increasing rearing height of oyster spat could

304 create an unwanted competition for space on the upper foreshore.

305 This study is based on the observation of a large number of oyster batches spread over the

306 entire farming area at different tidal heights and over several sampling periods. This effort

307 was made possible by the establishment of a volunteer network, thus highlighting its

308 usefulness and power in marine epidemiology studies. In comparison, conventional 
experimental approaches are generally conducted on a more local scale and involve comparing final survival at two or three tidal heights in a restricted number of batches. However, associating observed mortalities with OsHV-1 was possible owing to the simultaneous presence of a long-term oyster mortality monitoring network with a scientific experiment carried out in the same location. Further hypothesis-driven controlled experiments are needed to elucidate the mechanism of increased disease resistance with tidal height. Although citizen science has proven useful for marine epidemiology, more local hypothesis-driven research remains essential to uncover mechanisms underlying ecological patterns (Dickinson et al., 2010).

\section{Acknowledgments}

320 We thank all the oyster farmers who participated to field work and the RESCO network for providing high-frequency temperature, survival and OsHV-1 data. We thank Gaetan Daigle for advice on statistics, Clément Maréchal for gathering GIS data and Sébastien Petton for helping with bathymetric data. This work is part of the Gigassat project funded by the French National Research Agency No. ANR-12-AGRO-0001.

\section{References}

327 Agreste 2014. Chute de l'huître en Bretagne- Sud, progression de la moule en Bretagne$328 \quad$ Nord. In Recensement de la conchyliculture 2012. Ed. by Direction Régionale de l'Alimentation, de l'Agriculture et de la Forêt - Service régional de l'information statistique et économique. (AHAW). EFSA Journal, 13. 
Alfaro, A. C., Nguyen, T. V., and Merien, F. 2018. The complex interactions of Ostreid herpesvirus 1, Vibrio bacteria, environment and host factors in mass mortality outbreaks of Crassostrea gigas. Reviews in Aquaculture.

Azema, P., Maurouard, E., Lamy, J. B., and Degremont, L. 2017. The use of size and growing height to improve Crassostrea gigas farming and breeding techniques against OsHV1. Aquaculture, 471: 121-129.

Barbosa Solomieu, V., Renault, T., and Travers, M.-A. 2015. Mass mortality in bivalves and the intricate case of the Pacific oyster, Crassostrea gigas. Journal of Invertebrate Pathology, 131: 2-10.

Ben-Horin, T., Lenihan, H. S., and Lafferty, K. D. 2013. Variable intertidal temperature explains why disease endangers black abalone. Ecology, 94: 161-168.

Buestel, D., Ropert, M., Prou, J., and Goulletquer, P. 2009. History, status, and future of oyster culture in France. Journal of Shellfish Research, 28: 813-820.

Burge, C. A., Mark Eakin, C., Friedman, C. S., Froelich, B., Hershberger, P. K., Hofmann, E. E., Petes, L. E., et al. 2014. Climate Change Influences on Marine Infectious Diseases: Implications for Management and Society. Annual Review of Marine Science, 6: 249277.

Burrell, V. G., Bobo, M. Y., and Manzi, J. J. 1984. A comparison of seasonal incidence and intensity of perkinsus marinus between subtidal and intertidal oyster populations in South Carolina. Journal of the World Mariculture Society, 15: 301-309.

Connell, J. H. 1972. Community Interactions on Marine Rocky Intertidal Shores. Annual Review of Ecology and Systematics, 3: 169-192.

Cox, D. R. 1972. Regression Models and Life Tables. Journal of the Royal Statistical Society: Series B (Statistical Methodology), 20: 187-220.

de Kantzow, M., Hick, P., Becker, J. A., and Whittington, R. J. 2016. Effect of water temperature on mortality of Pacific oysters Crassostrea gigas associated with microvariant ostreid herpesvirus 1 (OsHV-1 $\mu$ Var). Aquaculture Environment Interactions, 8: 419-428.

de Kantzow, M. C., Hick, P. M., Dhand, N. K., and Whittington, R. J. 2017. Risk factors for mortality during the first occurrence of Pacific Oyster Mortality Syndrome due to Ostreid herpesvirus-1 in Tasmania, 2016. Aquaculture, 468: 328-336. 
de Lorgeril, J., Lucasson, A., Petton, B., Toulza, E., Montagnani, C., Clerissi, C., Vidal-Dupiol, J., et al. 2018. Immune-suppression by OsHV-1 viral infection causes fatal bacteraemia in Pacific oysters. Nature Communications, 9: 4215.

Dégremont, L. 2011. Evidence of herpesvirus (OsHV-1) resistance in juvenile Crassostrea gigas selected for high resistance to the summer mortality phenomenon. Aquaculture, 317: 94-98.

Degremont, L., and Benabdelmouna, A. 2014. Mortality associated with OsHV-1 in spat Crassostrea gigas: role of wild-caught spat in the horizontal transmission of the disease. Aquaculture International: 1-15.

Dégremont, L., Garcia, C., and Allen Jr, S. K. 2015. Genetic improvement for disease resistance in oysters: A review. Journal of Invertebrate Pathology, 131: 226-241.

Delisle, L., Petton, B., Burguin, J. F., Morga, B., Corporeau, C., and Pernet, F. 2018. Temperature modulate disease susceptibility of the Pacific oyster Crassostrea gigas and virulence of the Ostreid herpesvirus type 1. Fish \& Shellfish Immunology, 80: 7179.

Dickinson, J. L., Zuckerberg, B., and Bonter, D. N. 2010. Citizen Science as an Ecological Research Tool: Challenges and Benefits. Annual Review of Ecology, Evolution, and Systematics, 41: 149-172.

Fleury, E., Normand, J., Lamoureux, A., Bouget, J.-F., Lupo, C., Cochennec-Laureau, N., Petton, S., et al. 2018. RESCO REMORA Database : National monitoring network of mortality and growth rates of the sentinel oyster Crassostrea gigas. SEANOE.

Foster-Smith, J., and Evans, S. M. 2003. The value of marine ecological data collected by volunteers. Biological Conservation, 113: 199-213.

Harvell, C. D., Kim, K., Burkholder, J. M., Colwell, R. R., Epstein, P. R., Grimes, D. J., Hofmann, E. E., et al. 1999. Review: Marine ecology - Emerging marine diseases - Climate links and anthropogenic factors. Science, 285: 1505-1510.

Helmuth, B. 1999. Thermal biology of rocky intertidal mussels: Quantifying body temperatures using climatological data. Ecology, 80: 15-34.

Heral, M. 1989. Traditional oyster culture in France. Barnabe Aquaculture, Ellis Horwood. Hougaard, P. 1995. Frailty models for survival data. Lifetime Data Analysis, 1: 255-273.

Kaplan, E. L., and Meier, P. 1958. Nonparametric Estimation from Incomplete Observations. Journal of the American Statistical Association, 53: 457-481. 
Lafferty, K. D., Harvell, C. D., Conrad, J. M., Friedman, C. S., Kent, M. L., Kuris, A. M., Powell, E. N., et al. 2015. Infectious diseases affect marine fisheries and aquaculture economics. Annual Review of Marine Science, 7: 471-496.

Le Bihan, V., Catalo, M., and Le Bihan, J. in press. Reorganization of the value chain activities of oyster companies on the Atlantic coast following health crises in France (20062013). Marine Policy.

Malek, J. C., and Breitburg, D. L. 2016. Effects of air-exposure gradients on spatial infection patterns of Perkinsus marinus in the eastern oyster Crassostrea virginica. Diseases of Aquatic Organisms, 118: 139-151.

Malek, J. C., and Byers, J. E. 2017. The effects of tidal elevation on parasite heterogeneity and co-infection in the eastern oyster, Crassostrea virginica. Journal of Experimental Marine Biology and Ecology, 494: 32-37.

Paul-Pont, I., Dhand, N. K., and Whittington, R. J. 2013. Influence of husbandry practices on OsHV-1 associated mortality of Pacific oysters Crassostrea gigas. Aquaculture, 412413: 202-214.

Paul-Pont, I., Evans, O., Dhand, N. K., and Whittington, R. J. 2015. Experimental infections of Pacific oyster Crassostrea gigas using the Australian ostreid herpesvirus-1 (OsHV-1) $\mu$ Var strain. Diseases of Aquatic Organisms, 113: 137-147.

Peeler, E. J., Reese, R. A., Cheslett, D. L., Geoghegan, F., Power, A., and Thrush, M. A. 2012. Investigation of mortality in Pacific oysters associated with Ostreid herpesvirus-1 $\mu$ Var in the Republic of Ireland in 2009. Preventive Veterinary Medicine, 105: 136143.

Pepin, J. F., Riou, A., and Renault, T. 2008. Rapid and sensitive detection of ostreid herpesvirus 1 in oyster samples by real-time PCR. Journal of Virological Methods, 149: $269-276$.

Pernet, F., Barret, J., Gall, P. L., Corporeau, C., Dégremont, L., Lagarde, F., Pépin, J.-F., et al. 2012. Mass mortalities of Pacific oysters Crassostrea gigas reflect infectious diseases and vary with farming practises in the Thau lagoon. Aquaculture Environment Interactions, 2: 215-237.

Pernet, F., Barret, J., Marty, C., Moal, J., Le Gall, P., and Boudry, P. 2010. Environmental anomalies, energetic reserves and fatty acid modifications in oysters coincide with an exceptional mortality event. Marine Ecology-Progress Series, 401: 129-146. 
Pernet, F., Fuhrmann, M., Petton, B., Mazurié, J., Bouget, J.-F., Fleury, E., Daigle, G., et al. 2018. Determination of risk factors for herpesvirus outbreak in oysters using a broadscale spatial epidemiology framework. Scientific Reports, 8.

Pernet, F., Lupo, C., Bacher, C., and Whittington, R. J. 2016. Infectious diseases in oyster aquaculture require a new integrated approach. Philosophical Transactions of the Royal Society of London. Series B: Biological Sciences, 371: 20150213.

Pernet, F., Tamayo, D., and Petton, B. 2015. Influence of low temperatures on the survival of the Pacific oyster (Crassostrea gigas) infected with ostreid herpes virus type 1. Aquaculture, 445: 57-62.

Petton, B., Boudry, P., Alunno-Bruscia, M., and Pernet, F. 2015. Factors influencing diseaseinduced mortality of Pacific oysters Crassostrea gigas. Aquaculture Environment Interactions, 6: 205-222.

Petton, B., de Lorgeril, J., Mitta, G., Daigle, G., Pernet, F., and Alunno Bruscia, M. in revision. Fine-scale temporal dynamics of a polymicrobial infection in the Pacific oyster (Crassostrea gigas) using an ecologically-realistic experimental pathosystem. Disease of Aquatic Organism.

Petton, B., Pernet, F., Robert, R., and Boudry, P. 2013. Temperature influence on pathogen transmission and subsequent mortalities in juvenile Pacific oysters Crassostrea gigas. Aquaculture Environment Interactions, 3: 257-273.

Renault, T., Bouquet, A. L., Maurice, J.-T., Lupo, C., and Blachier, P. 2014. Ostreid herpesvirus 1 infection among Pacific oyster (Crassostrea gigas) spat: relevance of water temperature to virus replication and circulation prior to the onset of mortality. Applied and Environmental Microbiology, 80: 5419-5426.

Segarra, A., Baillon, L., Faury, N., Tourbiez, D., and Renault, T. 2016. Detection and distribution of ostreid herpesvirus 1 in experimentally infected Pacific oyster spat. Journal of Invertebrate Pathology, 133: 59-65.

Segarra, A., Baillon, L., Tourbiez, D., Benabdelmouna, A., Faury, N., Bourgougnon, N., and Renault, T. 2014. Ostreid herpesvirus type 1 replication and host response in adult Pacific oysters, Crassostrea gigas. Veterinary Research, 45: 1-10.

Silvertown, J. 2009. A new dawn for citizen science. Trends in Ecology \& Evolution, 24: 467471. 
459

460

461

462

463

464

465

466

467

468

469

470

471

472

473

474

475

476

477

478

479

480

481

482

483

Soletchnik, P., Mazurie, J., Pernet, F., Benabdelmouna, A., Bouquet, A. L., Petton, B., Blin, J. L., et al. 2011. Les pratiques culturales peuvent-elles permettre de réduire la surmortalité du naissain d'huîtres creuses? Récapitulatif des essais d'élevage et expérimentations zootechniques menés sur le territoire français entre 2008 et 2010.

Somero, G. N. 2002. Thermal Physiology and Vertical Zonation of Intertidal Animals: Optima, Limits, and Costs of Living. Integrative and Comparative Biology, 42: 780-789.

Su, M.-A., Huang, Y.-T., Chen, I. T., Lee, D.-Y., Hsieh, Y.-C., Li, C.-Y., Ng, T. H., et al. 2014. An Invertebrate Warburg Effect: A Shrimp Virus Achieves Successful Replication by Altering the Host Metabolome via the PI3K-Akt-mTOR Pathway. PLOS Pathogens, 10: e1004196.

Ugalde, S. C., Preston, J., Ogier, E., and Crawford, C. 2018. Analysis of farm management strategies following herpesvirus (OsHV-1) disease outbreaks in Pacific oysters in Tasmania, Australia. Aquaculture, 495: 179-186.

Whittington, R. J., Dhand, N. K., Evans, O., and Paul-Pont, I. 2015a. Further observations on the influence of husbandry practices on OsHV-1 $\mu$ Var mortality in Pacific oysters Crassostrea gigas: Age, cultivation structures and growing height. Aquaculture, 438: 82-97.

Whittington, R. J., Hick, P. M., Evans, O., Rubio, A., Alford, B., Dhand, N., and Paul-Pont, I. 2015b. Protection of Pacific oyster (Crassostrea gigas) spat from mortality due to ostreid herpesvirus 1 (OsHV-1 $\mu$ Var) using simple treatments of incoming seawater in land-based upwellers. Aquaculture, 437: 10-20.

Widdows, J., Bayne, B., Livingstone, D., Newell, R., and Donkin, P. 1979. Physiological and biochemical responses of bivalve mollusks to exposure to air. Comparative Biochemistry and Physiology a-Physiology, 62: 301-308. 
484 Table 1. Model parameter estimates from the Cox regression model. The columns display

485 the parameter name, the degrees of freedom that are associated with the parameter (df),

486 the estimated parameter value, the standard error of the parameter estimate (SE), the Wald

487 chi-square statistic, and the associated p-value for testing the significance of the parameter.

\begin{tabular}{|c|c|c|c|c|c|c|}
\hline Parameter & Level & $\mathrm{df}$ & Estimate & SE & $x^{2}$ & $P$ \\
\hline Origin & Hatchery & 1 & 0.597 & 0.127 & 21.9 & $<0.0001$ \\
\hline Tidal height & _ & 1 & -0.171 & 0.050 & 11.5 & 0.0007 \\
\hline Tidal height $\times$ Origin & Hatchery & 1 & -0.498 & 0.075 & 44.0 & $<0.0001$ \\
\hline Site & - & - & - & - & 58.5 & $<0.0001$ \\
\hline
\end{tabular}

488 

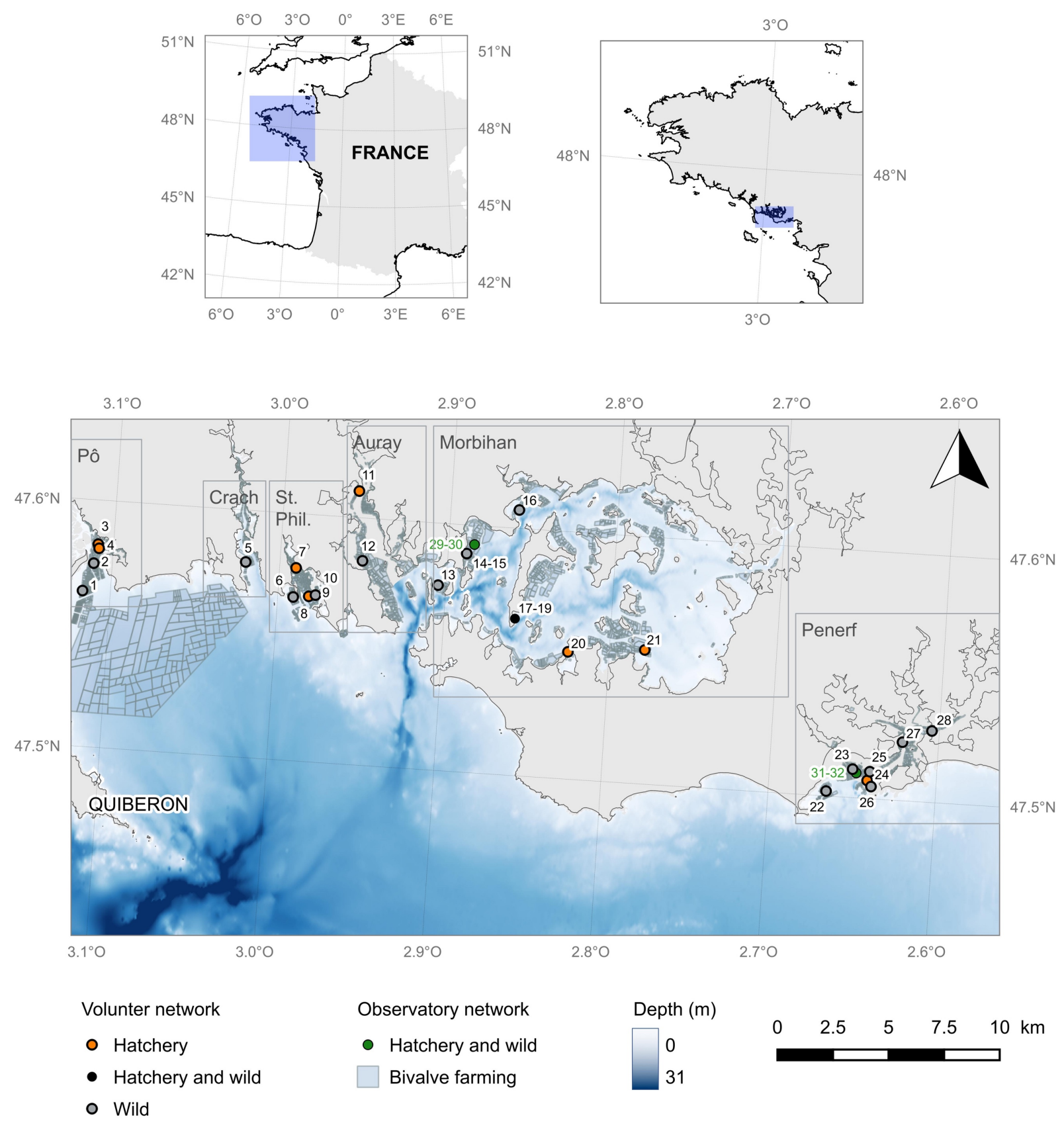

491 Figure 1. Spatial distribution of oyster survival monitoring sites. 


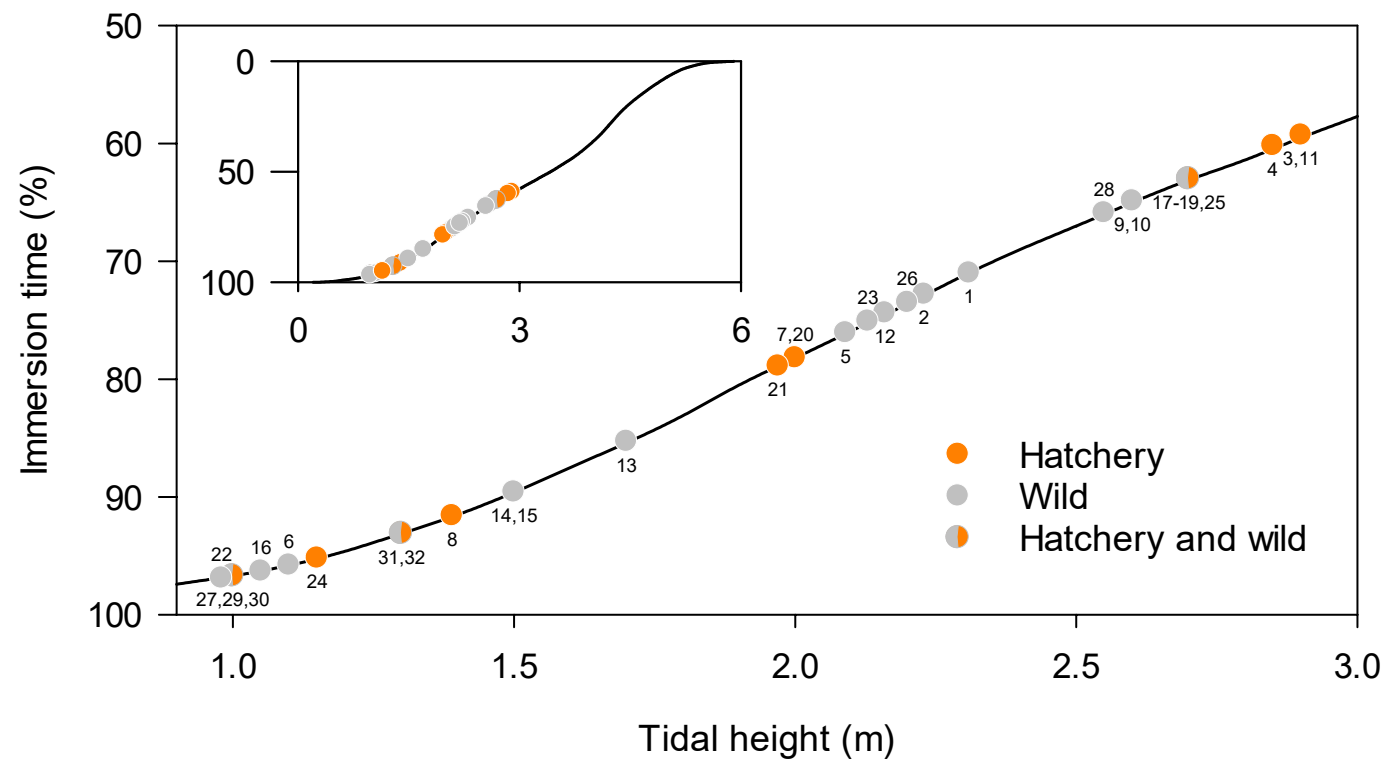

494 Figure 2. Relationship between immersion time and bathymetry. Circles represent the 495 position of the oyster survival monitoring sites. Inset shows the entire bathymetric range 496 during the period of study.

497
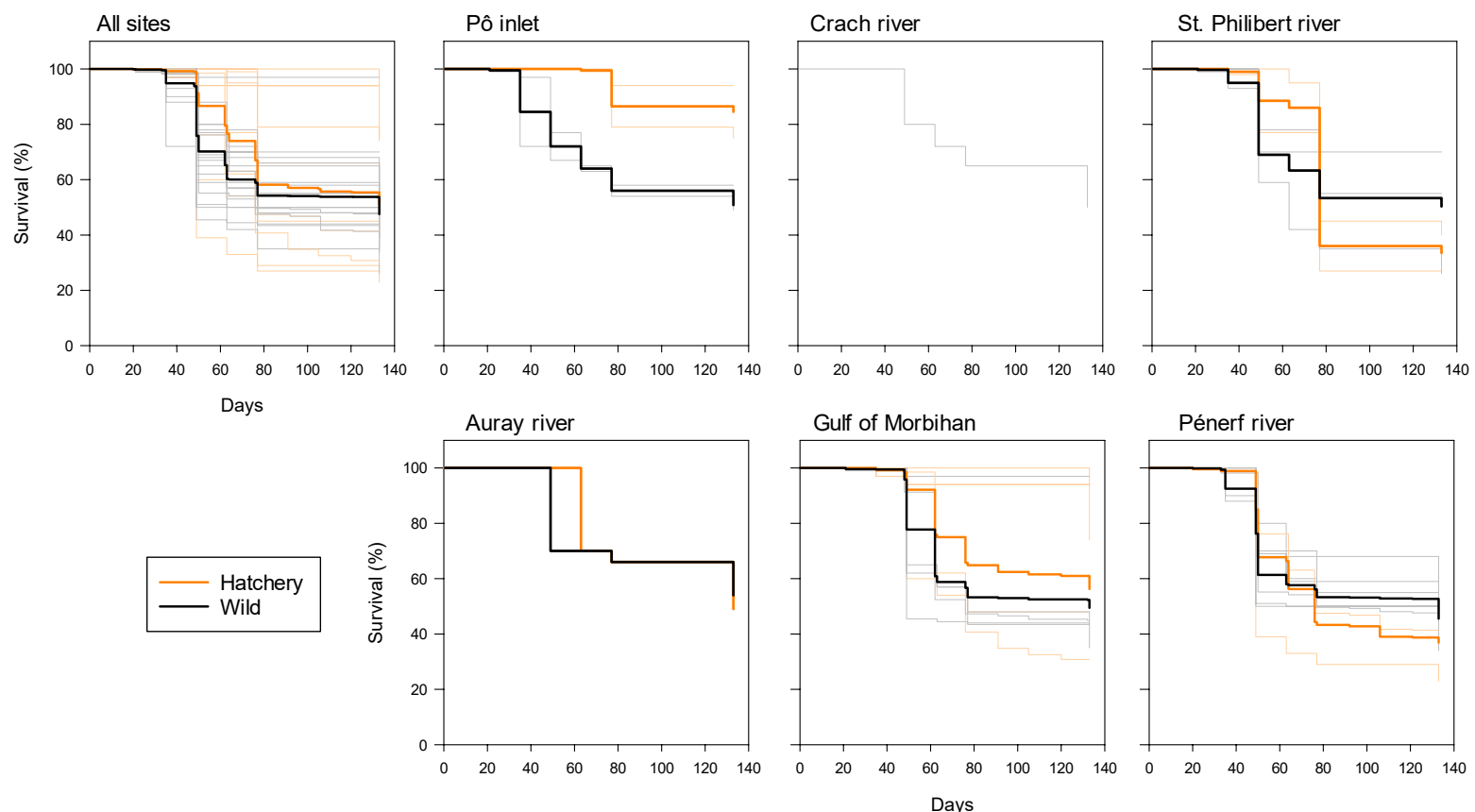

499 Figure 3. Survival of oysters. Thick lines represent the average survival per origin. Day 0 corresponds to 8 May 2013. 


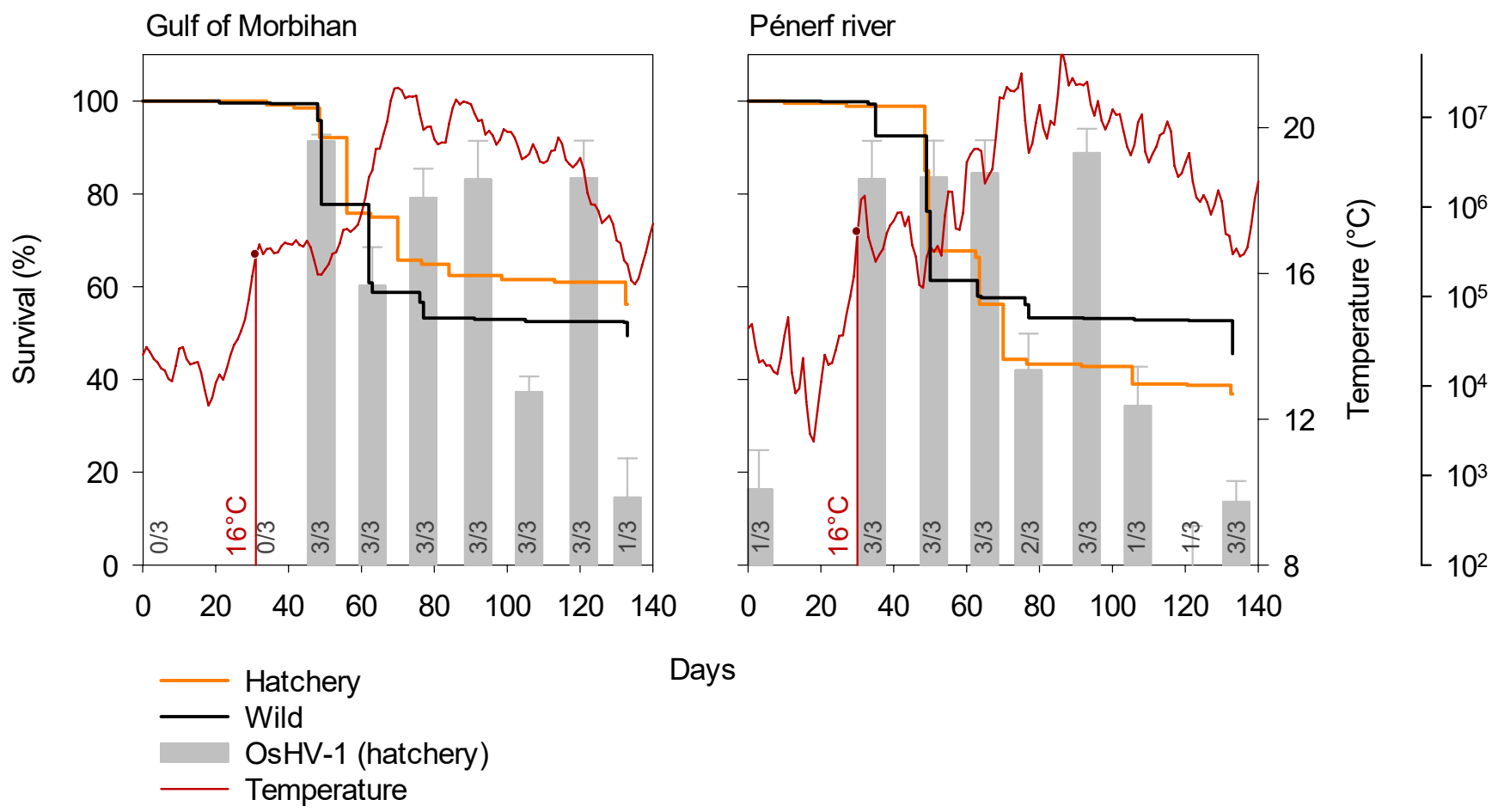

501

502 Figure 4. Oyster survival in two sites from the Ifremer observatory network in relation with 503 seawater temperature and OsHV-1 DNA detection. Left axis: survival functions of wild and 504 hatchery oysters. Right axis: evolution of seawater temperature and levels of OsHV-1 DNA in 505 oyster tissues collected in hatchery oysters (mean $\pm S D, n=3$ pools of 3 individuals). Ratios 506 indicate the number of positive samples out of the total number analysed. Day 0 correspond 507 to 8 May 2013. 


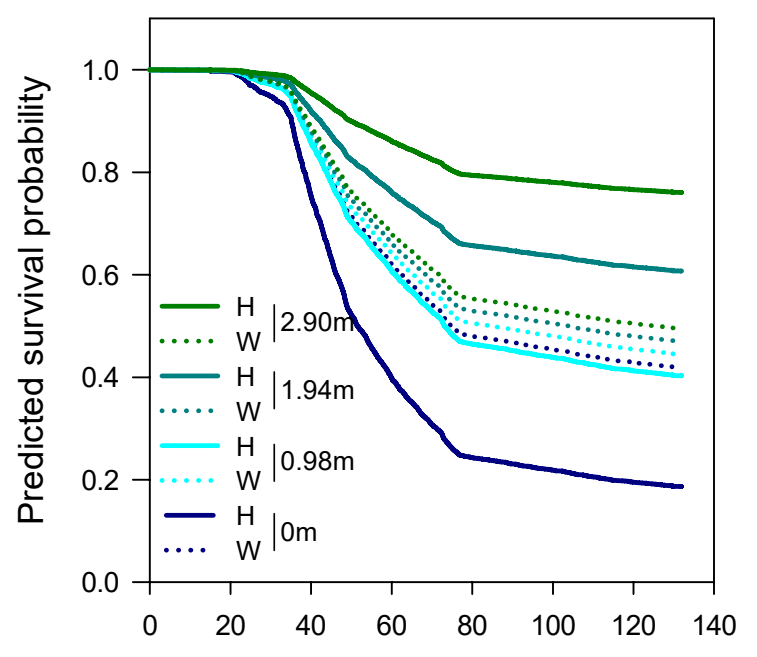

Days

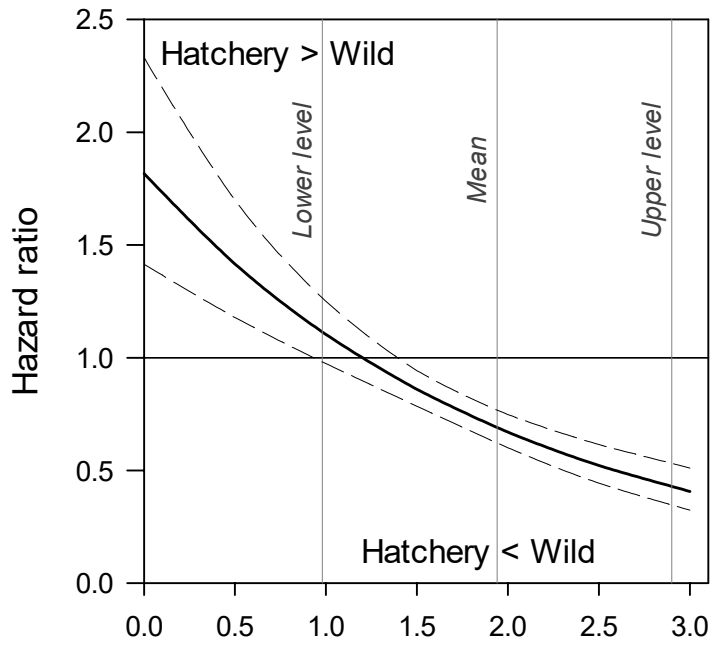

Tidal height (m)

Figure 5. Predicted survival probability curves of oysters as a function of tidal height and origin

511 of oysters (A). Hazard ratio of hatchery vs. wild oysters as a function of tidal height (B). Day 0

512 corresponds to 8 May 2013. Tidal height of $0 \mathrm{~m}$ represents permanent immersion whereas

$5130.98,1.94 \mathrm{~m}$ and $2.9 \mathrm{~m}$ were the lowest, the average and the highest level recorded in our

514 study. Values predicted at tidal height $<0.98 \mathrm{~m}$ are extrapolations. 